\title{
Language and Witchcraft as a Trade: Insights from Machakos County, Kenya
}

\author{
Gatitu Kiguru \\ kiguru.gatitu@ku.ac.ke \\ Kenyatta University \\ Phyllis W. Mwangi \\ mwangi.phyllis@ku.ac.ke \\ Purity M. Nthiga \\ nthiga.purity@ku.ac.ke \\ Caryn Kimuyu \\ carynkimuyu94@gmail.com
}

\begin{abstract}
Witchcraft is defined as the use of magical powers to cast spells, heal, see into the future or cause harm. Belief in the powers of witchcraft is widespread in Africa, and, as a consequence, people from different walks of life seek various forms of interventions from witchdoctors. As such, witchcraft in Africa is a trade, complete with a marked use of language that sustains it in modern society. This article reports on an analysis of language used by witchdoctors in Machakos County in Kenya, and respondents' views about witchcraft. The objectives of the study were twofold: the first was to identify and describe the language strategies that mark witchcraft as a trade, and the second was to explore the socio-psychological factors governing the use of language by witchdoctors. The primary data were collected through recorded interviews with the witchdoctors. To this end, two witchdoctors - one male and one female - were purposively sampled. In addition, a questionnaire was administered to 20 respondents to collect their views about witchcraft. The analysis found that witchdoctors use various language strategies to attract and retain clientele and that these strategies are a factor of the socio-psychological environment in which the witchdoctors operate. Moreover, the study established that witchdoctors still find relevance in modern Kenyan society because of prevalent beliefs about social and medical problems. Language, then, is an important tool in the witcheraft trade as it serves to purposely obscure meaning and shroud the trade in secrecy, enhance social exclusion and sustain belief in the magical powers of the witchdoctors.
\end{abstract}

Keywords: witchdoctors, supernatural powers, beliefs, language strategies 


\section{Background}

Kenyan society identifies itself largely as Christian. Indeed, the 2009 National Housing and Population Census report puts the religious composition of the country as follows: Christian $83 \%$ (of which $47.7 \%$ are Protestant, $23.4 \%$ are Catholic, and $11.9 \%$ are other Christians), Muslim 11.2\%, Traditionalists $1.7 \%$, Hindu $1.6 \%$, none $2.4 \%$ and unspecified $0.2 \%$. These statistics show that only a very small part on the population $(1.7 \%)$ reported themselves as Traditionalists in the census. However, both small rural towns and big urban cities in Kenya are awash with posters advertising the services of witchdoctors. Using supernatural powers only they can access and harness, these doctors' claim to have solutions for spiritual, social and medical problems. These include: low libido, missing persons, stolen property, asthma, diabetes, problems caused by jinni, curses, jealous relatives, workmates and neighbours and ill-luck in business, not to mention cheating husbands.

In addition, there are numerous sensationalist reports in both print and electronic media on witches, witchcraft, witchdoctors and their powers. These media stories are on: the criminal and the tragic (the lynching of people believed to be witches), the bizarre (thieves going insane, having bloated stomachs or eating grass as a result of a spell cast by witchdoctor), and the comical (illicit lovers 'stuck' in compromising positions so that a witchdoctor has to be called in to separate them). There are also media reports (local and regional) on aspirants for political office seeking the services of witchdoctors in order to guarantee their win in elections.

\subsection{Witchcraft, Law and Language}

There is a legal angle to witchcraft in Kenya. The country has a Witchcraft Act CAP 67 which prohibits witchcraft and stipulates penalties under the following eight sections:

Person pretending to exercise witchcraft, etc.

1. Witch-doctor supplying advice or articles for witchcraft with intent to injure.

2. Persons using witch medicine with intent to injure.

3. Possession of charms as an offence.

4. Charging persons with witchcraft.

5. Attempt to discover crime by witchcraft.

6. Chief permitting the practice of witchcraft.

7. District Commissioner may order person practising witchcraft to reside in specified place. 
It can be argued that the Act shows that the law recognizes witchcraft as an undesirable practice in society which needs to be outlawed. However, the Act is problematic in various ways. To start with, the commencement date of the Act was 12 November, 1925 and it has never been amended (KLRC, 2017). The Act was written under colonial rule and, like many other laws then, became part of Kenyan law after independence in 1963. This would suggest that Kenyans have never really had a say or a debate about the Act. Advocating a review of the Act, the Kenya Law Reform Commission [KLRC] (2017) notes that there is a thin line between witchcraft and religion and that the 2010 Kenyan Constitution asserts that Kenya is a secular state with no prescribed or proscribed state religion. Further, it is argued that we cannot ignore the interconnectedness of the belief in witchcraft and African culture. The Commission asserts that witchcraft is "still central not only in 'rural' societies but in 'high-class' societies as well." The arguments cement our position that witchcraft in Kenyan society needs scholarly attention in order to foster a critical look at the practice, the practitioners and the society that seek the services of witchdoctors. This article seeks to make a contribution to this by focusing on how language is used to mark out witchcraft as a trade.

The second problem with the Witchcraft Act is one of definition. The Act fails to define that which it seeks to prohibit. The prohibitions in the Act have phrases like "person pretending to exercise witchcraft", "Any person who bolds bimself out as a witchdoctor..." "Any person, professing a knowledge of socalled witchcraft...", and "Any person who, of his pretended knowledge of so-called witchcraft..."This kind of phrasing seems to suggest there are those who pretend to be witchdoctors and those who really are, and also embodies the implication that the knowledge and the witchcraft are not real. The KLRC (2017) concludes that the proposition (in the Act) that witchcraft does not exist but yet can cause injury to another in mind, person or property is untenable."

But what is pertinent to this article is the fact that the definitional confusion in the law is likely to translate to a confusion in the courts. In a case at the High Court of Kenya (Athumani v. Republic 1967) the court observes: Is it not possible, it may be asked, that honest though strangely deluded witchdoctors exist...there may well be men who undertake the cure of ailments for reward and have an honest belief in the efficacy of rituals, incantations and the like. With regard to this ruling, Mutunga (1976) observes that given the lack of definitional clarity in the law on what witchcraft is and who a witchdoctor is, courts are left with the challenge of deciding cases on the basis of whether or not the evidence before them shows the existence of an honest witchdoctor'. We propose that particular language use, and an analysis of the speech acts intended to be achieved by such language use, could be one criterion of determining an honest witchdoctor'. 


\subsection{Talking about Witchcraft}

As already noted, there are numerous and varying reports in the Kenyan media on the subject of witchcraft. Some of these are critical pieces on the place of witchdoctors in Kenyan society. The government-owned Kenya News Agency [KNA] (2017) poses the question 'Are witch doctors breaking the law in helping catch criminals?' The post notes an emerging trend in which self-professed witchdoctors have become 'unusually bold' and attract media coverage by purporting to use their powers to solve crimes. The report further notes that 'various professionals and law enforcement agencies have varied and conflicting opinions on whether self-confessed witchdoctors are engaging in criminally liable activities.' Wanyonyi (2008) reports along the same lines in an article provocatively headlined 'Witches rival police in crime war'. Such media reports show a society divided with regard to the role and place of a witchdoctor despite legal prohibitions.

Chanji (n.d.) reports that witchdoctors are now ready to legalize their business and pay taxes. The media report continues to say that a Member of Kwale County Assembly was sponsoring a motion that would help 'recognise genuine practitioners and weed out frauds' in the witchdoctor trade. In contrast, Oruko (2012) reports a parliamentary committee issuing a demand that the law on witchcraft be enforced. The report says that the committee of the National Assembly had demanded that the Government enforce laws on witchcraft to deter people in the coastal region from 'embracing retrogressive, negative and harmful traditional practices.' Given that Kwale County is in the coastal region, the view of the House Committee is clearly contradictory to that of the elected local government representative reported in the previous article.

A poll by Ipsos Synnovate - Kenya (cited in Thatiah, 2017) on half a million women in Kenya aged between 21 and 70 reports that half of them had visited a 'mganga' (witchdoctor) in the previous 7 years. Further, 38\% of those polled reported that they were repeat customers of witch doctors. They sought these services for help with financial problems and straying partners. The report further notes that $80 \%$ of the polled women said they were Christians.

These media reports show the conflicting views on witchcraft in Kenya. They thus inform the rationale for the need for scholarly study of this phenomenon. They are also the foundation of the questionnaire the study uses to collect perceptions on the role of witchdoctors in modern Kenyan society. 


\subsection{Power in Witchcraft or Power in Believing?}

The very existence of the supernatural and its influence on the physical and social world has always been a subject of fierce scholarly debate (Dawkins, 2006; Firestone, 2014; Kemp, 2000; Shook, 2010). The merits of these arguments, or lack thereof, is not the focus of this paper. However, this paper does take these arguments as evidence that human beings have the mental capacity to believe: a capacity that manifests when we say we believe and even when we say we do not believe. Talk about witchdoctors and their power is therefore talk in the realm of belief.

This paper argues that it is in this realm that witchdoctors find their relevance, derive their power and exercise their influence. Their power and influence partly lie in their use of language to make clients believe. Thus, a witchdoctor is as powerful as $\mathrm{s} /$ he is able to tap into and direct our innate power to believe.

Therefore, a visit to a witchdoctor is an invitation to partake in a symbolic game in which both the client and the witchdoctor agree to act certain roles. However, for the powers of the witchdoctor to 'work', the actors have to do more than act: they have to believe (at least the client should). This paper explores some of the language strategies witchdoctors use to manufacture belief in their clientele.

\section{Theoretical Background}

Witchdoctors continue to have relevance in Kenyan society despite competition from dominant world religions and modernity. Practitioners package their service in ways that ensure the survival of their trade. Those who dabble in dark magic are surrounded by an inescapable stigma. Given this, it is important to find out which language strategies define witchcraft as a trade, and, which ones ensure that the trade and its practitioners have some degree of acceptability in society. These are the strategies that help witchdoctors remain in business despite scepticism and competition from other groups in the business of providing solutions to social, spiritual and medical problems. Equally important are the social and psychological determinants of how these practitioners of witchcraft use language the way they do. The issues under focus in this article straddle the disciplines of law, psychology, advertising, communication religion and linguistics. 


\subsection{Language Use by Witchdoctors $\$$ Persuasion vs. Manipulation}

As traders operating in a given social space, witchdoctors acknowledge that, like other traders, they use language to achieve very specific goals. One of these goals is to attract or entice clients and convince them to buy the service on offer. Another is to hook clients to keep coming back. This is the character of modern day trade where both multinational corporations and individual traders engage advertising and marketing activities to sell what they have to offer. The Oxford Learner's Dictionary defines the verb 'advertise' as the activity of telling people about a product or service with the aim of encouraging them to use it. However, the use of language to influence the choice and behaviour of others is fraught with ethical dilemma.

Scholars distinguish between persuasion and manipulation. From a legal perspective, Sunstein (2015) demarcates the two concepts, noting that in 'persuasion, people are given facts and reasons, presented in a sufficiently fair and neutral way' (p. 80). In contrast, a manipulative act seeks to influence people's choices or behaviour but there is no sufficient engagement 'or appeal to their capacity for reflection and deliberation' (p.82). He further notes that the problem with manipulation is that choosers are coerced into making a choice without time or room for sufficient assessment of cost and benefits to themselves. We argue that this is the problem with witchdoctors. Purporting to have powers that only they can access and control, they give their clients little time or room for logical decision making. In fact, they actively discourage reason as it is not compatible with their trade. The 'doctors' engage in linguistic manipulation that mainly focuses on the emotional wellbeing of the client. They engage in what Asya (2013) labels as non-productive manipulation where language is used by the manipulator to assign him/herself a superior role and to relegate the hearer to an inferior position in which s/he feels compelled to submit to the demands of the manipulator. The fact that people share their personal problems with the 'doctors' leaves them vulnerable to all manner of manipulation.

From a psychological perspective, Handleman (2009) defines manipulation as the interference in the decision making process of another... by employing questionable tricks such as temptation, distraction and misdirection' (p. ix). He categorises manipulation into two categories: limiting manipulation and expanding manipulation. In the former, the manipulator seeks to narrow the choices one can make while in the latter, the manipulator seemingly expands the choices but the 'expanded horizon' still serves the goal of the manipulator. At the heart of the two types of manipulation is biased language use. 
From a marketing perspective, Prelipceanu (2013) observes that modern marketing practices are aggressive and aim to control the mind of the target customers' ( $p$ 248). To achieve this aim, advertisers 'use a variety of techniques to arrest our attention, to gain our trust, to stimulate our desire for the product or service'. She identifies ten such techniques, some of which are language based. These are association, intensifying and weasel words, use of celebrities and the use of plain folks. Others are flattery, bribery, scientific evidence, exaggeration, humour and explicit claims. This list contains the mainstream advertising strategies used by corporates of all sizes. It is interesting to see whether some of these strategies are adopted by witchdoctors given that the service they sell is not mainstream but illegal.

Dancu (2014) groups marketing acts into a continuum that ranges from the use of coercion or force to manipulation. Among the specific manipulative acts are deceit, fallacious arguments and emotive persuasion. With regard to emotional manipulation, Dancu (2014) notes that both corporations and governments use fear to cause the public to take panicked decisions. This is particularly the case with regard to health issues such as cancer and HIV/AIDS. As already noted, witchdoctors claim to cure terminal and chronic illnesses. Since they have no training in modern medicine, we seek to identify the strategies they use to convince patients they can cure these conditions.

Perhaps the most important theoretical approach to the concept of manipulation is that espoused by van Dijk $(2003,2006)$. Working within the framework of Critical Discourse Analysis, van Dijk (2006) regards manipulation as a discursively constructed concept achieved through talk-in-interaction. He adds that even in everyday usage, manipulation has negative connotations because 'a manipulator exercises control over other people, usually against their will or against their best interests' Van Dijk further notes that manipulation involves power abuse as 'manipulators make others believe or do things that are in the interest of the manipulator, and against the best interests of the manipulated' (p. 360).

In terms of analysis, van Dijk (2006) proposes that discourse features need to be studied in terms of their contextual environment. This is because no structural feature is inherently manipulative. Manipulation is the result of how specific participants use given features in particular contexts. Thus, our analysis of language use by witchdoctors is heavily dependent on the context in which they use language. Van Dijk $(2003,2006)$ also proposes analytical categories for manipulative discourse. These range from global structures to the local structures that express the global ones. Whether global or local, these structures are used to discursively construct the manipulator in a good light while the 'other' is depicted 
negatively. Some of the strategies include lexical, syntactic and rhetorical choices, and the use of sounds and visuals. These categories will inform the analysis in this article.

\section{Methodology}

This study sought to answer the following questions.

1. What language strategies used by witchdoctors mark witchcraft as a trade?

2. What socio-psychological factors govern the use of language by witchdoctors?

To this end, the study adopted qualitative methods to collect and analyse data. Mulemba-Mukengeshayi (cited in Luyaluka, 2017) notes the methodological challenge of studying witchcraft. He proposes either a direct personal experience approach that would involve some form of formal initiation into witchcraft for the researcher or the abstractive approach that looks at witchcraft as a social reality that can be studied by looking at its diverse expression in real life. Luyaluka (2017) proposes an empirical methodology, the starting point of which is the recognition of the 'scientificity' of African epistemology (as opposed to reducing African religious belief to just superstition).

Without delving into the merits, or lack thereof, of these methods, this article adopts the abstract induction approach suggested by Mulemba-Mukengeshayi (cited in Luyaluka,2017). The paper adopts the view that, whatever interpretations and connotations are attached to witchcraft, witchdoctors are social actors with a certain degree of influence. The media reports cited earlier are a testament to the fact that despite professing the dominance of the Christian faith and a continued pursuit of a Western lifestyle, Kenyan society still has a place for the witchdoctor.

This is in no way a contradiction. Scholars have documented the presence and influence in, or parallels between, traditional occult practices and modern day institutions such as universities (Wood, 2014; 2010a; 2010b) and private corporations (Jean \& Comaroff, 1999). Their studies suggest that the old does not fade away; it reinvents itself. Through an analysis of language use by witchdoctors and the views of Kenyans, this paper seeks to show that witchcraft has reinvented itself as a trade. This reinvention has been forced by the modern realities of change, innovation and completion. 


\subsection{The Data}

The data for this study were collected in Machakos County in Kenya from two sources: 20 adult respondents and 2 self-professed witchdoctors. A questionnaire was administered to the 20 respondents who were purposively sampled to equally represent men and women. The responses to the questionnaire provided data on the prevalence of the belief in the powers of witchdoctors in the locality of the study and the standing of witchdoctors in the society.

Two witchdoctors, one female and one male, were purposively sampled for interviews. Permission to audio record the interviews was given through signed consent forms. The audio recordings were transcribed and, together with the researcher's observations during the interview sessions, formed the basis for analysing the language strategies meant to enhance the witchdoctors work as a trade, the way witchdoctors perceive themselves and their place in society and the significance of language in their trade.

\section{Analysis of the Results}

\subsection{Views on the Place and Role of the Witchdoctor in Kenya}

This section reports on the views collected through the questionnaires administered to 20 adult respondents. The choice of the respondents factored in gender representation of 10 men and 10 women. The six-item questionnaire collected information on whether the respondents had ever sought, would consider seeking or knew of someone who had ever sought the services of a witchdoctor. It also sought the respondents' views on a professed Christian seeking the services of a witchdoctor, and whether there were problems that only a witchdoctor could help solve. The results for each question are presented below.

\subsubsection{Question One: Have you ever sought the services of a witchdoctor?}

Of the 20 respondents, 6 ( 2 women and 4 men) reported they had at some time sought the services of a witchdoctor while 14 ( 8 women and 6 men) responded that they had not. This was a very direct question given that involvement in the occult can attract a lot of stigma. Given this, it is significant that 6 respondents responded to the very pointed question in the affirmative. The second and third questions took a softer approach. 


\subsubsection{Questions Two and Three}

+ Would you consider seeking such services?

- Do you know anyone who has sought such services?

Unlike the first question, questions two and three were less direct. With regard to question two, 9 respondents ( 4 women and 5 men) said they would consider seeking help from a witchdoctor. This question was only posed to the 14 respondents who had responded negatively to question one. Thus, of the 14 who had said they had never sought the services of a witchdoctor, only 5 said they would not even consider it.

With regard to question Three, it is telling that 18 respondents reported they knew of 'someone' who had visited a witchdoctor. The two dissenting voices came from women. This question was the 'softer' version of Question One, given the vagueness of the pronoun 'someone'. The expectation was that respondents would be more at ease reporting their own visits under the indirect 'someone'. While not arguing for statistical representativeness, we find it significant that 18 out of 20 adult respondents reported knowing someone who had visited a witchdoctor. This is an indicator that the services of these traditional healers are still sought nowadays.

Given the dominant view (backed by census data) that Kenya is predominantly Christian, the next question sought to find out if the respondents took issue with professed Christians seeking help from witchdoctors.

\subsubsection{Question Four: Is it an issue for a Christian to seek such services?}

The responses to this question patterned as follows. A total of 15 (9 male and 6 female) respondents saw nothing wrong with a Christian seeking the services of a witchdoctor. This would suggest that many people in Kenyan society see no contradiction in traditional and Christian beliefs co-existing. This proposition is further affirmed by an analysis of responses to Question Five below.

\subsubsection{Question Five: Are there problems that only a witchdoctor can solve?}

The responses to Question Five were a replica of those to Question Three. Most of the respondents were of the opinion that some problems can only be solved by witchdoctors. This group also responded to the sixth question which sought to identify the problems that only witchdoctors can solve. Here, all the respondents were unanimous that the solution to a problem is determined by its cause. Thus, whereas a myriad of medical and social problems (chronic illnesses, extreme poverty, stagnation in business and life etc.) were cited, what is significant is the 
uniform explanation that if the problem at hand is caused by witchcraft, jinni, ancestral curses, non-adherence to customary practices or breaching of taboos, the solution lies in tradition.

This may explain why the witchdoctor still has a role to play in a modern and Christian society. A significant number of people believe that modernity, with all its knowledge and belief systems, does not have a solution to the problems they are experiencing. For whatever personal or social reasons, such people look to traditional superstitions and belief systems for solutions. The witchdoctor is a representative of such traditional superstitions and belief systems but is shaped by modern forces. The modern day witchdoctor may not have all the power that tradition availed him, but he has adapted. The next section presents the language strategies used by modern-day witchdoctors that characterize their profession as a trade.

\subsection{Language Strategies by Witchdoctors that Mark Witchcraft as Trade}

The use of the honorific 'daktari' (Kiswahili word for doctor) stands out in the advertisements that witchdoctors place on all manner of available space including electricity poles. The honorific title is shared by medical doctors, $\mathrm{PhD}$ holders and, in the Kenyan context, traditional herbalists. During the interviews, it was noted that the witchdoctors use the honorific to refer to themselves.

1. Mimi kama daktari ninasaidia watu, sio kuwafanyia mabaya.

As a doctor I treat people, I do not harm them.

The title 'doctor' confers some degree of sophistication and legitimacy to witchdoctors and helps them carve out a niche in a modern world that puts a lot of emphasis on respectable professions.

Moreover, the title enables witchdoctors to enter into the arena of those who cure modern diseases. Witchdoctors do not restrict themselves to evil spirits and good luck charms. As 'doctors', they claim to have cures for chronic diseases like asthma, diabetes and HIV. We argue that the use of the honorific daktari is thus strategic as it allows witchdoctors to enter the realm of modern medicine. The usage is what van Dijk (2006) refers to as positive representation of self.

Witchdoctors work with the narrative that the client provides. In doing so, they assign meanings to the clients description of problems and magnify the threat. Asked to explain the assistance they give to a client who reports a missing person, one of the witchdoctors interviewed said: 
2. Namwabia anielezee... ananileza anatokawapi na mambo ya yumbani kwake. Akishanielezea ninatumia kititi nanauliza wazee kama buyu mtu ako bai na ako wapi.

I ask for details...the client has to tell me where he comes from and things about the home. After s/he tells me, I use the kititi and ask the wazee whether this person is alive or dead.

The response to the same question by the other witchdoctor interviewed is strikingly similar.

3. Namwambia anielezee buyu mtu alipotea lini, mwaka gani... amepotea miaka ngapi. Pia ananieleza kubusu watu hapo nyumbani ndio niweze kuonana nani amesababisha buyo kupotea.

I ask him/her to tell me when the person disappeared, which year.., for how many years s/he she has been missing. He also tells me about the other people at home so that I can see who caused the person to disappear.

None of the two witchdoctors interviewed claimed total powers of divination: problems have to be explained and relevant details of the case given before the witchdoctors can use their powers to provide a solution. We conclude that it is the client's own story that enables problems to be supposedly identified and solutions crafted. This view is given further credence by a report in a local daily by Njung'e (2011) who tells of a visit to a witchdoctor with a sob story' about an imaginary straying husband. She reports that having listened to her story, the witchdoctor, a Dr. Halima, who claimed to be from Zanzibar, told her that the other woman had sought the services of a powerful witchdoctor who had bewitched the husband. Dr. Halima warned her client that unless they moved fast, she would never see her husband again. In this instance, the witchdoctor uses the client's story to create her own and to amplify the original threat the client felt she was facing.

Witchdoctors also use the strategy of symbolic incantations and invoking the gods. They purport that the spoken word in the form of chanting has a phenomenal and supernatural power that can be invoked to remedy any situation and perform the impossible. When asked about the language they use to treat clients, the doctors emphasise its mystery and power.

4. Ile maneno ninatumia iko nanguvu sana. Natumia lugha ya zamani sana kuongea na wazee. Hata niki sema bakuna mtu mwingine anweza kuelewa. Hii maneno ikona nguvu nandio ina fanya mambo ina fanyika. Kama mtu amepotea, nikimuita na bio lugha atarudi nyumbani hata aki wawapi. Hi maneno ndio inafunga mwizi mpaka ana rudisha mali yako naina mfunga hapo na bata inaweza kumfamya wazimu mpaka niulize wazee wamuachilie. 
The words I use are very powerful. I use an ancient language to talk to the wazee. When I speak, no one else can understand. These are powerful words that cause things to happen. If someone is missing, when I summon him/her in that language, s/he will return home no matter where $s / h e$ is. These words bind a thief until s/he returns your property and they root him to the spot and can even make him insane until I ask the wazee to release him.

This explanation shows that witchcraft is grounded in words: mysterious words that only the 'doctor' knows and which can work magic. It is clear that the explanation emphasizes that no one else can understand the language. It is a secret code that only the witchdoctor can access, and draw power from. There is also a clear similarity between the secret code of the witchdoctors and the jargon that characterizes modern-day professions. The effect of both seems to be the same: marking membership and mystifying non-members.

The other witchdoctor interviewed said that at times the clients themselves are asked to chant or repeat what he tells them. However, whereas the clients will use normal language, the witchdoctor uses a special language with the power to communicate with spirits. He emphasised the power and mystery of the language.

5. Hii lugha nili pata kutoka kwa nyanya yangu ambaye alikuwa ni mghanga. Maneno ninayosema yanatibu. Siwezi tibu bila biyo maneno. Hio lugha ikiisha, hata bii kazi yangu itakwisha.

I got this language from my grandmother who was a witchdoctor. The words I say cure. I cannot treat without those words. If this language ceases, so does my work.

His observation emphasises the fact that witchcraft is a trade of words: it is through words that the trade is practised and transmitted from one generation to the next. This last observation is significant because by saying that the craft was passed down to him by his grandmother, the witchdoctor in this case is laying claim to the reverence given to age old traditions that have served the community over the years. Moreover, he shows that his trade is a calling which parallels the 'call to serve the Lord' espoused by Christians.

The other language strategy used by witchdoctors is transferring agency to wazee (Kiswahili for "elders") who are to be understood as ancestral spirits of gods. This means that it is really the power of the spirits at work rather than that of the witchdoctor. Njunge (2011) reports that Dr. Halima had told her that she had to 'offer a "gift" to appease the wazee' she would consult on her behalf, adding that the wazee would not accept anything less than KES 1,000 (about 10 USD) as a consultation fee. 
The issue of wazee dictating the fee to be paid to the witchdoctor comes out in the interview. Asked how they determine what each client should pay, both the witchdoctors responded by distancing themselves from the task of setting the payment amount.

6. Hioni mambo ya wazee. Wazee ndio wanasema kile wanataka. Mimi siwezi kuitisha zaidi au kidogo yaile wazee wanasema.

That is for the wazee. It is the wazee who say what they want. I cannot ask for more or less than what the wazee say.

7. Mimi ninauliza wazee. Mtu akisema hana pesa ama ako na kidogo mimi nauliza wazee. Wao ndio wanafanya kazi. Wao ndio natuma hata kwa boma ya $m t u$ kutoa majini. Kwa bivyo bao ndio wanaamua mtu atatoa pesa ngapi.

I ask the wazee if a client says he has no money or has little. I ask the wazee. They are the ones who do the work. They are the ones I send to someone's house to remove evil spirits. Therefore, they are the ones who decide how much a client will pay.

The last point is quite telling as it introduces the aspect of bargaining into the client-witchdoctor encounter. It would seem that payment is negotiable subject, of course, to agreement by wazee.

As well as determining payment, wazee are also given the agency of visiting homesteads to neutralize any harmful medicine buried there or to evict evil spirits. The wazee have to be kept happy by the client who must honour any payments demanded either in kind or money. A delay in a solution or the failure of a prescribed solution is likely caused by the wazee being unhappy.

8. Ukipatia wazee kile wanataka basi shida yako ina kwisha. Lakini ukindanganya wazee utajiletea shida... shida yako haiwezi kwisha. Hata mambo mabaya ziadi yanaweza kuku pata.

If you give the wazee what they want then your problems end. But if you lie to the wazee you will bring problems to yourself... your problems cannot end. Even worse calamities might befall you.

This captures a not too subtle carrot-and-stick approach by the witchdoctors. If a client keeps the wazee happy, his problems are solved and if they are not, then it is likely that $\mathrm{s} / \mathrm{he}$ angered the wazee. In this case, the blame goes back to the client and not the witchdoctor. The shift in agency therefore makes it impossible for clients to blame the witchdoctors should their cures fail to work.

Witchdoctors style themselves as the nemesis of witches (those who use their craft to harm rather than help people). This attempt at appropriating 
good motives for oneself is seen right from the catchy marketing phraseology witchdoctors use.

Advt 1: Dr Kamwana kutoka Kilif.

Dr Kamwana from Kilifi.

Sumu ya wachawi

Poison for witches

Advt 2: $\quad$ Dr Mizizi kutoka Kitui

Dr Mizizi from Kitui

Mizizi anatibu; mungu naponya

Mizizi treats; God cures

The first advert depicts the 'doctor' as the solution to the problem of witches who harm their fellow men. The second adopts the form of inscriptions common in many missionary hospitals in Kenya where doctors attribute the power to cure to a deity while they retain the lesser duty of treating. In this case, the witchdoctor partners himself with God and, by extension, with good. The adverts are examples of macro speech acts that attribute good acts to the doctors and bad acts to witches and thus discredit them (van Dijk, 2003, 2006).

The witchdoctors interviewed made the same point.

9. Mimi na saidia watu. Watu wenye wamesumbuliwa na wachawi au majini nina wasidia.

I help people. I assist those who have problems caused by witches and evil spirits.

10. Dawa yangu niyakusaidia. Inaharibu yale wachawi wamefanya. Machawi anaweza hata kukuua lakini mimi situmii dawa yangu kuua watu. Mtu akiniambia anataka dawa yakuua mwenzake siwezi kumpatia.

My medicine helps. It undoes what witches have done. A witch can kill you but I do not use my medicine to kill people. If someone tells me s/he wants medicine to kill another, I cannot give it to him.

This self-depiction is important given the media reports of members of the public lynching people suspected to be witches. In a society hostile to witches, a witchdoctor has to come up with an anti-witch identity for personal survival and also as a marketing strategy to attract clients who believe that the problems they have are the result of being bewitched.

Related to this, one of the witchdoctors alluded to a working relationship (mainly good) with established religions. One of the witchdoctors reported that he came from a Catholic background. He said that his parents and siblings were 
practising Catholics and that he himself goes to mass on Sunday. He claimed his priest had blessed his work and paraphernalia with holy water and forbidden him from harming anyone.

11. Mimi mwenyewe naenda kanisa. Mimi ni mkatoliki na watu wa familia yangu wote niwa katoliki. Padre wetu amewahi kuja hapa, akamawaga ile maji takatifu na akabariki vitu vyangu za kazi. Akaniambia nisitumie vitu zangu kudburu yeyote.

I personally go to church. I am a Catholic and my whole family is Catholic. The priest has come here; he poured holy water and blessed the instruments I use in my work. He told me never to use my instruments to harm anyone.

However, the second witchdoctor told of a not-so-cordial relationship with the local clergy largely because their congregants are his frequent clients.

12. Mimi natibu watu wote. Watu wanaenda kanisa nashida wanombewa lakini shida haiishi. Kwahivyo wanakuja kwangu na shida inaisha. Wanakuja kunishukuru na wanaleta wengine. Saa ingine bio inakasirisha hawa mapastor sababu watu wakanisa yao ndio wanakuja kwangu.

I treat all people. People go to church with problems; they are prayed for but the problems do not end. Therefore, they come to me and the problems end. They come to thank me and bring other people. Sometimes this angers these pastors because people from their churches come to me.

The reference here is to Pentecostal pastors who are irked by churchgoers going to witch doctors. Whether their anger is motivated by concern for the souls of their flock or the competition from the witchdoctor for the same clientele is a moot point.

Finally, each of the witchdoctors boasted of past successes and current popularity. They claimed to have served important and wealthy clients who had previously seen other witchdoctors without much success. The declaration in example 12 above 'They come to thank me and bring other people' is an example of these claims of success and popularity.

\subsection{Socio-Psychological Factors Governing the Use of Language by Witchdoctors}

To begin with, witchdoctors face inescapable stigma from the very society that seeks their services. To counter this, witchdoctors strive to present their nemeses, the witches, in a bad light while presenting themselves in a positive light.

Secondly, witchdoctors in Kenya face competition from dominant religious systems (Christianity and Islam), modernity and other witchdoctors. The witchdoctors interviewed explained some degree of cooperation with established 
religions. Their assertion is that Christianity does not have all the answers (many 'saved' people seek their services). In addition, they claim not to have any quarrel with Christian religious leaders or their flock. In any case, the witchdoctors claim that medical doctors and the church cannot deal with medical conditions whose genesis is witchcraft

Finally, witchdoctors are motivated by the need to remain relevant and to do business in a competitive environment. They have to 'hook' clients and make them believe, come back and bring others. This approach, we argue, is no different from the approaches adopted by business people and business organisations operating in present society.

\section{Conclusions}

Witchdoctors in Kenya are kept in business by the prevalent belief in society that some problems (social, medical etc.) have supernatural origins and therefore require supernatural solutions. Indeed, even professed Christians believe that the failure to follow certain customary practices can invoke the wrath of their ancestors: by claiming to have a link with these ancestors, witchdoctors ensure their own relevance. Motivated by the need to remain relevant and in business in a competitive environment, the doctors' adopt all manner of strategies to 'hook' their clients. Their approach to business, we argue, is no different from that adopted by business people and business organisations operating in present society.

We conclude that witchdoctors prey on the ignorance, gullibility and desperation of their clients. However, in the Kenyan context, they are not the only ones guilty of using language to mystify and retain a hold on the public for selfish gain. Politicians and miracle-touting prosperity-gospel preachers are perhaps more guilty given the scale of their influence. Moreover, there have been media reports of medical doctors recommending expensive tests and other procedures which patients (specifically cancer patients) do not need. The heart of the problem seems to be the extremely high levels of poverty and ignorance, leading to a power imbalance that favours both the established and pseudoprofessions. 


\section{References}

Asya, A. (2013)."Linguistic manipulation: Definition and types". In International Journal of Cognitive Research in Sciences. Engineering and Education, 1(2).

Chanji, T. (n.d.). "Witchdoctors now ready to legalise their business and pay taxes". Retrieved from <https://www.sde.co.ke/article/2000113795/ witchdoctors-now-ready-to-legalize-their-businesses-and-pay-taxes $>$.

Comaroff, J., \& Jean, J. (1999). "Occult economies and the violence of abstraction: Notes from the South African postcolony". American Ethnologist, 26 (2) 279-303.

Danciu, V. (2014). "Manipulative marketing: Persuasion and manipulation of the consumer through advertising". Theoretical and Applied Economics, XXI (2)19-34.

Dawnins, R. (2006). The God delusion. London: Bantam Press

Firestone, R. S. (2014).”Naturalistic vs. supernatural explanations: «Charting» a Course away from a belief in God by utilizing inference to the best explanation". Open Journal of Philosophy, 4, 281-302.

Handelman, S. (2009). Thought manipulation: The use and abuse of psychological trickery. Oxford: Praeger.

Keмp, K. W. (2000). "Scientific method and appeal to supernatural agency: A Christian case for modest methodological naturalism". LOGOS, 3 (2) 165 205

KLRC (2017, January 23). "Justification for review of Witchcraft Act, CAP 67". [Blog post] Retrieved from <http://www.klrc.go.ke/index.php/klrcblog/518-justification-for-review-of-witchcraft-act-cap-67>.

Luyaluka, K. L. (2017). "An empirical methodology of the study of witchcraft and its implementation in African cultures". Saudi Journal of Humanities and Social Sciences, 2 (8) 633-642.

Mutunga, O. K. (1971)."Witchcraft and the criminal law in East Africa". Valparaiso University Law Review, 5 (3) 524-555

Mwale, A. (2017, July 3)."Are witch doctors breaking the law in helping catch criminals?" Kenya News Agency.

National Council for Law Reporting (2012). Laws of Kenya: Witchcraft Act CAP 67. Nairobi: Government Press

Nuung'E, C. (2011, August 13). "My visit to a witchdoctor shows the depths one can sink to". Retrieved from <https://www.nation.co.ke/lifestyle/ lifestyle/My-visit-to-a-witchdoctor-shows-the-depths-one-can-sinkto/1214-1218232 ww6apm/index. Html>. 
Орнiambo, J. (2009, June 26). “Horror of Kenyas 'witch' lynching”. BBC News Retrieved from <http://news.bbc.co.uk/2/hi/africa/8119201.stm>.

Oruko, I. (2012, August 24). "Kenya: House committee wants witchcraft law enforced". The Star.

Prelipceanu, C. M. (2013). Advertising and language manipulation. Editura Muzeul Literaturii Romane.

Sноок, J. R. (2010). "Skepticism about the Supernatural". Retrieved from $<$ http://shook.pragmatism.org/skepticismaboutthesupernatural.pdf $>$.

Sunstein, C. (2016). "Fifty shades of manipulation". In The Ethics of Influence: Government in the Age of Behavioural Science. Cambridge: Cambridge University Press. doi: 10.1017/CBO9781316493021.005

Thatiah, J. (2017, March 31). "Half of women in Kenya have visited mganga, study finds". Retrieved from <https://www.nation.co.ke/lifestyle/saturday/ Half-of-Kenyan-women-have-visited-a-mganga/1216-3872504-keqoxg/ index.html

Van Dijk, T. A. (2006). "Discourse and manipulation". Discourse and Society, 17(2) 359-383.

VAN Dijk, T. A. (2003). Ideología y discurso. Barcelona: Ariel.

Wanyonyi, R. (2008, December 10). "Witches rival police in crime war". Retrieved from <https://www.standardmedia.co.ke/article/1144001324/ witches-rival-police-in-crime-war $>$.

Wood, F. (2014)."Kinship, collegiality and witchcraft: South African perceptions of sorcery and the occult aspects of contemporary academia". Tydskr. Letterkd [online], 51 (1) 150-162

Wood, F. (201oa)."Occult innovations in higher education: Corporate magic and the mysteries of managerialism". Prometheus: Critical Studies in Innovation, 28 (3) $227-44$.

Wood, F. (2010b). "Sorcery in the academy: Universities and the occult rituals of the corporate world". Southern African Journal for Folklore Studies, 1, 4-28 